\begin{tabular}{|l|l|l|}
\hline \multicolumn{2}{|c|}{ PublisherInfo } \\
\hline \hline PublisherName & $:$ & BioMed Central \\
\hline \hline PublisherLocation & $:$ & London \\
\hline \hline PublisherImprintName & $:$ & BioMed Central \\
\hline \hline
\end{tabular}

\title{
Use of cDNA microarrays in breast cancer
}

\begin{tabular}{|l|l|l||}
\hline \multicolumn{2}{|c|}{ ArticleInfo } \\
\hline \hline ArticleID & $:$ & 3633 \\
\hline \hline ArticleDOI & $:$ & $10.1186 /$ bcr-1999-66611 \\
\hline \hline ArticleCitationID & $:$ & 66611 \\
\hline \hline ArticleSequenceNumber & $:$ & 53 \\
\hline \hline ArticleCategory & $:$ & Paper Report \\
\hline \hline ArticleFirstPage & $:$ & 1 \\
\hline \hline ArticleLastPage & $:$ & 4 \\
\hline \hline & & RegistrationDate : 1999-9-20 \\
\hline ArticleHistory & $:$ & OnlineDate \\
\hline \hline ArticleCopyright & $:$ & Current Science Ltd1999-9-20 \\
\hline \hline ArticleGrants & $:$ & \\
\hline \hline ArticleContext & $:$ & 1305811 \\
\hline \hline
\end{tabular}




\section{Keywords}

breast cancer, cDNA, clustering, gene expression, microarrays

\section{Introduction}

The study of gene expression in breast tumors, as in most solid tumors, is hampered by heterogeneity of the cancer cells as well as contamination by other cell types present in the tissue. cDNA microarrays are a novel tool for the investigation of gene expression, and consist of thousands of different cDNA clones spotted onto known locations on glass microscope slides. These slides/microarrays are then hybridized with differentially labeled cDNA populations made from the mRNAs of two different samples. The primary data obtained are ratios of fluorescence intensity representing the ratio of concentrations of mRNA molecules that hybridized to each of the cDNAs represented on the array.

\section{Aims}

To identify physiologically relevant gene expression patterns in breast tumors using cDNA microarrays.

\section{Comments}

This is the first paper to apply cDNA microarray technology to the analysis of gene expression in human breast cancer tissue. The power of microarrays to generate vast amounts of data poses problems of processing, storing and retrieving the information and analyzing the results in the context of existing knowledge. Pat Brown?s group has pioneered the use of so-called 'clustergrams', which group together genes on the basis of their expression patterns. Web publication of extended data tables in the form of these complex clustergrams (on the PNAS\%20site), as well as a searchable database of all the microarray data (on their\%200wn\%20site), will no doubt serve to assist in the analysis and interpretation of such data derived from genome-wide expression experiments. 


\section{Methods}

The human mammary epithelial cell (HMEC) line was used as reference for all experiments. A series of in vitroexperiments were carried out on the HMEC line including addition of transforming growth factor (TGF)- $\beta 1$, withdrawal of epidermal growth factor (EGF), addition of interferon (IFN)- $\alpha$, IFN $-\gamma$, response to senescence, and growth on Matrigel.

Thirteen grade II-III, grossly dissected, infiltrating ductal carcinomas, as well as two normal breast samples and three immortal breast-derived cell lines were also analyzed. The cDNA microarrays were produced in collaboration with Incyte Pharmaceuticals, and consisted of 5531 human cDNA clones. A hierarchical clustering algorithm produced a table of results wherein the cDNAs of the array were grouped together based on similarities in their patterns of gene expression. The same algorithm was applied to cluster the experimental samples (ie cell lines and tumors) according to their overall patterns of gene expression.

\section{Results}

Given the wealth of data generated by these microarray experiments, it is no surprise that there were too many clusters of coexpressed genes with obvious relevance to breast cancer biology to be discussed by the authors in detail. Instead they have concentrated solely on certain clusters. A 'proliferation cluster' of genes, included the human homologue of the yeast CDC47 gene (MCM2), MCM3, MCM6, cyclin $\mathrm{B} 1$, and the proliferation-associated antigen Ki-67, was found to be highly expressed in the cell lines and a subset of the tumor specimens. Immunostaining with the proliferation marker Ki-67 showed a correlation with the expression level of the genes in the cluster. Six of the eight experimental treatments caused a significant reduction in the proliferation rate of these cultures, which was reflected by variation in the expression of genes in this cluster. An IFN-regulated gene cluster that was originally identified in vitro was also expressed by many of the tumors, although expression varied. Gene expression patterns that were contributed by non-epithelial cell types present in the breast were also found in these experiments. A cluster of genes including three different Immunoglobuling genes and the generic leucocyte antigen CD45 showed an expression pattern likely to have been contributed by B lymphocytes. This was confirmed by staining with the B lymphocyte cell surface marker CD20 of the tumor cells.

\section{Discussion}

Features of gene expression patterns were found which could be related to a complex physiological property (eg proliferation), the activity of specific signalling pathways (eg the IFN-regulated pathway), and the cellular composition of the tumors (eg the presence of B lymphocytes). The ability of this 
approach to classify breast tumors into categories based on shared gene expression patterns has been demonstrated here by use of the proliferation-associated and IFN-associated clusters. Discrete gene expression patterns that could be assigned to specific cell types also suggest that clustering analysis of cDNA microarray data from tumors can be interpreted without prior separation of the constituent cell types.

\section{References}

1. Perou CM, Jeffrey SS, Van de Rijn M, Rees CA, Eisen MB, Ross DT, Pergamenschikov A, Williams CF, Zhu SX, Lee JC, Lashkari D, Shalon D, Brown PO, Botstein D: Distinctive gene expression patterns in human mammary epithelial cells and breast cancers. Proc Natl Accad Sci USA. 1999, 96: 9212-9217. 